\title{
Interactions between Temozolomide and Quercetin
}

\author{
Okuma Emile Kasende* \\ Faculty of Science University of Kinshasa, \\ B.P. 190 Kinshasa XI, D. R. Congo \\ okuma.kasende@unikin.ac.cd \\ Vincent de Paul N. Nziko, Steve Scheiner* \\ Department of Chemistry \& Biochemistry Utah State University, \\ Logan, UT 84322-0300, USA \\ steve.scheiner@usu.edu
}

\begin{abstract}
Temozolomide and quercetin are both molecules with important pharmaceutical activity, whose effects can mutually enhance one another when clinically applied simultaneously. Quantum chemical calculations are used to examine how the two molecules might interact with one another. The most stabilizing force arises when the aromatic systems of the two molecules are arranged parallel to one another. These stacked configurations are reinforced by H-bonds, but geometries containing only H-bonds, without the aromatic stacking, are much less stable, even if the H-bonds are short and strong. Comparison between B3LYP and B3LYP-D binding energies allows an evaluation of dispersion energy, which is found to be a primary contributor to the stability of the stacked structures.
\end{abstract}

keywords: H-bonds; stacked structure; NBO; dispersion 


\section{INTRODUCTION}

Quercetin (QU) of general formula 3,3',4',5,7-pentahydroxyflavone represented in Figure 1 is a natural flavonoid, found in a broad range of fruits and vegetables, with a typical daily intake of about $30 \mathrm{mg}$. It has multiple biological, pharmacological and medical applications [1-4], and is one of the most potent antioxidants.<smiles>O=c1c(O)c(-c2ccc(O)c(O)c2)oc2cc(O)cc(O)c12</smiles>

Figure 1: Structure of quercetin (QU)

This molecule continues to attract the attention of numerous research groups because it also facilitates apoptosis of tumor cells $[1,3,4]$ such as those of Glioblastoma multiforme (GBM), the most common and the most aggressive primary brain tumor. GBM is ultimately recurrent. Despite enormous progress in the development of surgical techniques and radio- and chemotherapies, the treatment of malignant GBM is extremely difficult and can extend patients' lives by only a few months. Survival is significantly prolonged in patients with newly diagnosed GBM who are treated with Temozolomide (TMZ) (Figure 2) combined with radiotherapy [5]. However, TMZ treatment usually fails due to the chemoresistance of GBM cells. Therefore, the development of new treatment modalities to attenuate drug resistance and/or to enhance TMZ anti-tumor effects is required. 


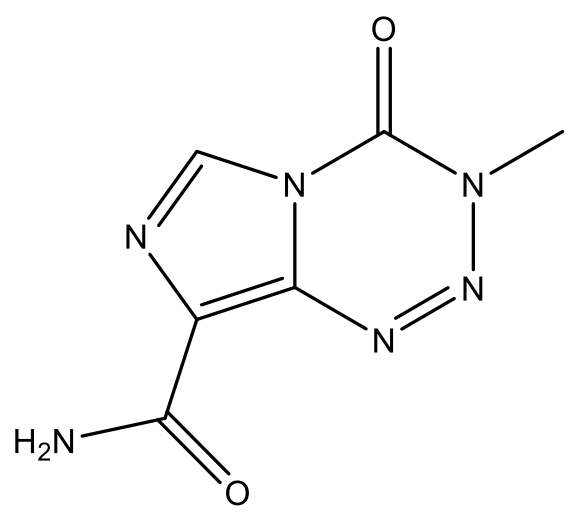

Figure 2: Structure of temozolomide (TMZ)

Searching to augment the anticancer potency of TMZ, some experiments reporting the effects of TMZ and QU on cell death in the human astrocytoma cell line MOGGCCM have indicated that QU acts in concert with TMZ when used in combination rather than in separate pharmacological applications [6-8]. Along the same line, Sang's in vitro experiments have demonstrated that TMZ alone effectively inhibited the viability of U251 and U87 cells [9]. When combined with QU, TMZ significantly inhibited cell viability. Neither TMZ nor QU alone affected caspase-3 activity and cell apoptosis, whereas TMZ combined with QU significantly increased caspase-3 activity and induced cell apoptosis. It was concluded that QU sensitizes human GBM cells to TMZ via inhibition of Hsp27 [9], indicating that QU and TMZ induce apoptosis very significantly, having no effect on autophagy induction.

Although a promising solution for GBM treatment, the combined pharmacologic interaction of TMZ and QU is not well understood. Specifically QU as a pentahydroxy flavonoid has 7 hydrogen bond (HB) acceptors, $5 \mathrm{HB}$ donors, and three possible chelating sites competing in complexation processes, as well as a strong intramolecular HB [10]. The presence of these HBs can help explain QU's biological multifunctionality. However, it is not entirely clear which of many possible conformers are most important. Assuming 2 possible orientations for each of the 5 hydroxyl groups, along with 2 possible orientations of hetero and modified phenyl rings, one obtains an a priori estimate of possible QU conformations as high as 64. On the other hand, MP2/6-311++G(d,p) // B3LYP/6-31G(d,p) conformational analysis suggests only 12 conformations with Gibbs energies within $5 \mathrm{kcal} / \mathrm{mol}$ of the most energetically favorable [10].

An extensive literature survey reveals that little work has been carried out concerning the noncovalent forces involving each of QU [10-14] and TMZ [15- 24]. Moreover, neither experimental nor theoretical work examining the interaction between TMZ and QU has been reported. This work examines via quantum chemical calculations the intermolecular recognition issues between $\mathrm{QU}$ and TMZ prodrugs. The 
full range of possible dimer geometries is calculated, and their relative energies and modes of binding elucidated. There is a wide range of non-covalent interactions that play roles in numerous biological processes [25-39]. The complexity of QU and TMZ is underscored by the presence of H-bonding groups, as well as extended rings. While the former would tend to bring the two molecules toward a structure with linear $\mathrm{AH} \cdot \mathrm{B}$ arrangements, the rings are likely to favor stacked geometries. This work is designed to determine how the competition between these two proclivities combines in the favored geometrical structures.

\section{METHODS}

While the global minimum of QU of course warrants careful examination, there is no guarantee that the most stable geometry of the monomer is present also when it combines with TMZ in a dimer. In addition to this global minimum QUA, a second structure was also considered, wherein a rotation of a hydroxyl group breaks the internal $\mathrm{OH} \cdot \cdot \mathrm{O} \mathrm{HB}$ and frees it up for an intermolecular interaction with TMZ. The optimized geometries of both QUA and the secondary minimum QUB are displayed in Fig 3. It is hoped that a comparison of the stabilities and structures of dimers formed between TMZ and QUA or QUB might yield insights into the influence of the chelating system upon the formation of the TMZ-QU dimers. With respect to $\mathrm{TMZ}$ it is fairly rigid, so is characterized by only two rotamers, separated by $1.4 \mathrm{kcal} \mathrm{mol}^{-1}$ at the G3MP2 level [40]. The more stable TMZ rotamer is considered in this work, although free rotation is permitted within the optimization procedure.

The geometries of TMZ-QUA and TMZ-QUB complexes were fully optimized using the M06-2X/6$31+\mathrm{G}(\mathrm{d}, \mathrm{p})$ protocol. Vibrational analysis verified each structure as a true minimum. Single point calculations of these heterodimers were carried out using B3LYP, B3LYP-D, $\omega$ B97XD and MP2, all with the $6-31+G(d, p)$ basis set [41-50]. As the potential energy surface of the dimer is apt to contain multiple minima, it was necessary to employ a range of different starting points for each geometry optimization, so as to avoid missing any minima. These optimizations were begun from a large number (100) of different starting points with all reasonable intermolecular configurations considered, including parallel, perpendicular, coplanar, and all sorts of mixed structures. The final group of non-repeating, fully optimized minima consisted of 12 distinct TMZ-QUA and eight TMZ-QUB dimer geometries. The binding energy BE of each TMZ dimer was derived as an electronic energy difference between the optimized dimer and the sum of the relaxed monomers in their optimized geometries. This binding energy was corrected for basis set superposition error (BSSE) [51] using the Boys-Bernardi counterpoise correction [52]. With respect to basis set, expansion of the set from $6-31+\mathrm{G}^{*}$ to $6-311++\mathrm{G}^{* *}$ showed no significant differences, in the context of the M06-2X functional. 
The dispersion energy was estimated as the difference in binding energy between B3LYP-D3 and B3LYP data as described by Equation (1). The molecular electronic energies E were computed by dispersion-corrected DFT given by Equation (2), in which EDFT is the (all-electron) KS-DFT SCF energy for a particular density functional, $\mathrm{E}^{(2)}$ disp is the standard atom pair-wise London dispersion energy from D3 theory [53] (using Becke-Johnson damping [54-56]), and $\mathrm{E}^{(3)}$ disp is a three-body dispersion term (of Axilrod-Teller-Mutto type [57,58]), which was calculated as described in reference [53] using program DFT-D3 [59].

$$
\begin{aligned}
& \text { Disp }=\mathrm{BE}_{(\mathrm{B} 3 \mathrm{LYP}-\mathrm{D} 3)}-\mathrm{BE}_{(\mathrm{B} 3 \mathrm{LY})} \\
& \mathrm{E}=\mathrm{E}_{\mathrm{DFT}}+\mathrm{E}^{(2)}{ }_{\text {disp }}+\mathrm{E}^{(3)}{ }_{\text {disp }}
\end{aligned}
$$

Calculations were performed using the Gaussian 09 software package [60,61]. Atomic charges and charge transfer energies were assessed by NBO 6.0 software [62]. GaussView and Chemcraft programs were used for visualization [63]. The (AIM) procedure [64,65] was applied to determine the presence of bond paths and the associated position and densities of bond critical points, using the AIMALL software [65] at the M062X/6-31+G(d,p) level.

\section{RESULTS AND DISCUSSION}

\section{$\underline{\text { Geometries and Energetics }}$}

As two molecules approach one another, their first recognition relates to the long-range electrostatic interaction. The molecular electrostatic potential (MEP) surrounding the QU molecule offers a glimpse into what an approaching TMZ molecule might see. This potential is displayed in Figure 4a where red and blue regions indicate, respectively, the most positive and negative regions of the potential. Positive regions occur in the vicinity of the $\mathrm{H}$ atoms, particularly hydroxyl groups. The $\mathrm{O}$ atoms of the hydroxyls are quite negative, as is the carbonyl $\mathrm{O}$. One may also observe a small blue region above the approximate center of the $\mathrm{C}_{5} \mathrm{O}$ ring, which could attract a negative region in the TMZ molecule. The corresponding MEP around TMZ [36,37] is illustrated in Fig 4b. It exhibits primary negative potential around its two $\mathrm{O}$ atoms, with positive regions around its $\mathrm{H}$ atoms and its six-membered ring.

The optimized structures of the QUA-TMZ heterodimer fall into two clearly defined categories. There is first a set of six stacked geometries where the TMZ molecule lies above and approximately parallel to the QU molecule, facilitating interactions between their respective $\pi$ systems. These stacked dimers, labeled ASn, are reinforced by HBs. The second set comprises six dimers, wherein H-bonding is the dominant characteristic, and where there is no such stacking; AHBn designations are applied to this set. Figs 5 and 6 depict respectively the three most stable stacked structures and the two H-bonding structures of lowest 
energies along with the atom-numbering scheme. The important characteristics of all twelve minima are reported in Table 1.

The structures are numbered in descending order of binding energy computed at the M06-2X level; these orders remain largely intact at other levels, with small deviations. There is a general pattern that MP2 binding energies are weaker than the three DFT levels. In most cases, M06-2X and $\omega$ B97-XD yield very similar results with B3LYP-D3 slightly weaker, but this difference fades for the HB, nonstacked dimers. The stacked geometries are generally the most stable, with the five most stable structures all of this type.

Considering first the stacked structures in Table 1, the DFT binding energies vary from a maximum of some $75 \mathrm{~kJ} / \mathrm{mol}$ down to about $50 \mathrm{~kJ} / \mathrm{mol}$. NBO identifies a O-H $\cdots \mathrm{O} \mathrm{HB}$, only $1.883 \AA$ in length, as the dominant specific interaction in $\mathrm{AS} 1$, with $\mathrm{E}(2)=40.2 \mathrm{~kJ} / \mathrm{mol}$. This $\mathrm{HB}$ also benefits from a $\mathrm{O}_{7}-\mathrm{H}_{10}\left(\sigma^{*}\right) \leftarrow$ $\mathrm{C}_{21}-\mathrm{O}_{9}(\pi)$ transfer with $\mathrm{E}(2)$ equal to $10.75 \mathrm{~kJ} / \mathrm{mol}$. The $\mathrm{O}_{7}-\mathrm{H} \cdots \mathrm{O}_{9} \mathrm{HB}$ is supplemented by a pair of weaker $\mathrm{C}-\mathrm{H} \cdots \mathrm{O}$ HBs with $\mathrm{E}(2)=5.98$ and $3.35 \mathrm{~kJ} / \mathrm{mol}$. Of the stacked geometries, AS2 contains an $\mathrm{E}(2)=57.82$ $\mathrm{kJ} / \mathrm{mol}$, and AS8 is even larger with $\mathrm{E}(2)=72.28 \mathrm{~kJ} / \mathrm{mol}$. The nonstacked structures display even stronger HBs, e.g. AHB6 for which $\mathrm{E}(2)=126.4 \mathrm{~kJ} / \mathrm{mol}$ and AHB7 with $\mathrm{E}(2)=115 \mathrm{~kJ} / \mathrm{mol}$. Indeed, NBO suggests little in the way of other types of bonding for these geometries.

Given the strong HBs in the pertinent geometries, it is important to understand why the stacked geometries tend to be more stable. NBO shows little in the way of specific charge transfers, other than HBs, that would account for their very low energies. And these HBs are not strong enough to account for their full binding energy. For example, if one were to invoke the relationship [60] between $\mathrm{HB}$ energy $\mathrm{E}_{H B}$ and AIM potential energy density $\mathrm{V}(\mathrm{r})$ at the corresponding bond critical point, $\mathrm{BCP}\left(\mathrm{E}_{H B}=\mathrm{V}(\mathrm{r})_{\mathrm{BCP}} / 2\right)$, the $\mathrm{E}_{H B}$ of the HBs in AS1 amount to $21 \mathrm{~kJ} / \mathrm{mol}$ or less than $30 \%$ of the total binding energy.

The parallel arrangement is conducive to a particularly large dispersion attractive force. This sort of attraction does not show up readily in an NBO analysis, which focuses on specific charge transfer. One means of estimating the contribution of dispersion is via a comparison of the B3LYP and B3LYP-D3 binding energies, as the latter has been designed so as to explicitly evaluate the dispersion energy that is not contained within the original B3LYP formalism. The relevant binding energies are compiled in Table 2, followed in the last column by their difference, which can be roughly considered as the dispersion energy. It may immediately be noted that the stacked geometries are characterized by a large dispersion attraction, varying between 64 and $101 \mathrm{~kJ} / \mathrm{mol}$. This range can be compared with the dramatically smaller values for the HB structures in Table 2, varying between 16 and $23 \mathrm{~kJ} / \mathrm{mol}$. In fact, prior to inclusion of dispersion, the B3LYP interactions of the ASn dimers are all repulsive. 
The NBO values of E(2) refer to a perturbative treatment of charge transfer between individual localized orbitals, from an occupied orbital on one monomer to a vacant one on its partner. The quantities in Table 1 do not include intramolecular charge transfers, nor the changes thereof that occur upon dimerization. As such, sums of $\mathrm{E}(2)$ cannot be equated with induction energy. Nonetheless, it is tempting to consider these sums as a rough approximation to the intermolecular charge transfer component, even if only in a qualitative sense. Taking stacked structures AS1 and AS2 as examples, the sums of E(2) in Table 1 amounts to 60 and $77 \mathrm{~kJ} / \mathrm{mol}$, respectively. A large component of this quantity in each case arises from one or more HBs. Structure AHB6, in contrast is a purer H-bonded structure, and as such contains a much larger $\mathrm{E}(2)$ element, summing to $147 \mathrm{~kJ} / \mathrm{mol}$.

As mentioned above, $\sum \mathrm{E}(2)$ cannot be equated with induction so one cannot directly compare this sum with the dispersion energies in Table 2. The fact that the dispersion energy of $89 \mathrm{~kJ} / \mathrm{mol}$ for AS1 in Table 2 is larger than $\sum \mathrm{E}(2)$ does not therefore prove that this dimer is dispersion-dominated, any more than the opposite trend (64 vs $77 \mathrm{~kJ} / \mathrm{mol}$ ) suggests the induction control for AS2. For this same reason, the sum of $\sum \mathrm{E}(2)$ and dispersion cannot be taken as a correct measure of binding energy.

\section{Heterodimers Involving Secondary Minimum QUB}

As indicated above, the internal $\mathrm{OH} \cdot{ }^{\circ} \mathrm{O} \mathrm{HB}$ which adds to the stability of the QU monomer can inhibit the ability of the involved $\mathrm{OH}$ and carbonyl $\mathrm{O}$ atoms to participate in interactions with an incoming TMZ molecule. For this reason, the QUB rotamer, with this internal HB disrupted, was also considered to engage in interactions with TMZ. The optimized structures of the QUB-TMZ heterodimer fall into two very clearly defined categories. There is first a set of five stacked geometries where the TMZ molecule lies above and approximately parallel to the QUB molecule, facilitating interactions between their respective $\pi$ systems. Some of these stacked dimers are reinforced by HBs. The second set comprises three unstacked structures, engaged primarily in H-bonding. Figs 7 and 8 depict respectively the three most stable stacked structures and the two HB structures of lowest energies. The important characteristics of all eight minima are reported in Table 3.

The structures are numbered in descending order of binding energy computed at the M06-2X level; these orders remain relatively intact at other levels with the primary exception of BS2 whose stability is probably exaggerated by M06-2X. As in the earlier cases of the QUA dimers, one again sees a general pattern that MP2 binding energies are a bit weaker than the three DFT levels. In most cases, M06-2X and $\omega \mathrm{B} 97-\mathrm{XD}$ yield very similar results with B3LYP-D3 slightly weaker, but this difference is barely noticeable for the coplanar dimers. 
Considering first the stacked structures in Table 3, the DFT binding energies vary from a maximum of some $85 \mathrm{~kJ} / \mathrm{mol}$ down to roughly half that amount. NBO identifies a $\mathrm{O}-\mathrm{H} \cdots \mathrm{O} \mathrm{HB}$ as the dominant specific interaction in BS1, with $\mathrm{E}(2)=45 \mathrm{~kJ} / \mathrm{mol}$ and only $1.884 \AA$ in length, as depicted in Figure 7 . In addition to this HB, NBO signals a variety of transfers to $\pi^{*}$ antibonding orbitals. Like BS1, both BS2 and BS3 show evidence of a $\mathrm{OH} \cdot \mathrm{O}$ HB between the two molecules, supplemented by other weak interactions. The parallel arrangement is conducive to a particularly large dispersion attractive force as is discussed in some detail below.

The H-bonded BHBn dimers in Table 3 also span a wide range of binding energies, with DFT values between 38 and $72 \mathrm{~kJ} / \mathrm{mol}$. Within this set of three dimers, there is unanimity concerning their ordering, although there are of course disagreements as to the absolute magnitudes. As in the case of the stacked structures, the three DFT methods yield similar binding energies, larger than MP2. BHB1 is the most stable HB dimer, but is bound more weakly than the three most stable stacked structures. All three HB minima rely upon several HBs for their stability. BHB1 contains four separate and identifiable HBs, with a cumulative $\mathrm{E}(2)$ of $244 \mathrm{~kJ} / \mathrm{mol}$. There is some correlation between the total binding energies of the three coplanar dimers and their cumulative NBO measure of HB strength.

Clearly then, the greater stability of the stacked geometries, with their paucity of identifiable specific interactions such as HBs, can be attributed to dispersive forces. As above dispersion was estimated as the difference between the B3LYP and B3LYP-D3 binding energies. The relevant binding energies are compiled in Table 4, followed in the last column by their difference. It may immediately be noted that the stacked geometries are characterized by a large dispersion attraction, varying between 69 and $89 \mathrm{~kJ} / \mathrm{mol}$. This range can be compared with the dramatically smaller values for the HB structures, varying between 11 and $20 \mathrm{~kJ} / \mathrm{mol}$.

The italicized numbers in the BE columns allow comparisons between the dimers formed by QUB with its more stable congener QUA. Each of these numbers corresponds to the energy of the indicated complex, relative to the most stable dimer considered here, AS1. It is quickly observed that the total energies of the QUB complexes with TMZ are considerably higher than this global minimum on the surface. In other words, the greater binding energies of some of the QUB complexes are unable to compensate for the considerably higher energy of the QUB monomer relative to QUA.

\section{CONCLUSIONS}

Quercetin interacts with temozolomide to form a large number of stable dimers. The structures of these complexes can be categorized in one of two ways. In the most stable dimers, the aromatic systems of the two molecules are roughly parallel to one another, in a stacked arrangement. These complexes are 
stabilized by a large amount of dispersion energy. The binding strength is usually supplemented by one or more H-bonds. But the heterodimers stabilized solely by HBs, with no stacking between the two molecules, are less stable than the parallel arrangements, even if the HBs are short and strong.

The overall binding energies of the complexes can be quite large, as much as $80 \mathrm{~kJ} / \mathrm{mol}$. There is general agreement among the DFT functionals: M06-2X, $\omega$ B97XD, and B3LYP-D3 concerning the binding energies, although the first two tend to yield slightly larger values than the last. Despite its reputation for exaggerating stacking energies, MP2 predicts considerably weaker binding energies.

\section{Acknowledgments}

O.E.K. would like to thank the Council for International Exchange of Scholars (CIES) for a Fulbright Visiting Scholar grant at Utah State University. Computer, storage and other resources from the Division of Research Computing in the Office of Research and Graduate Studies at Utah State University are gratefully acknowledged. 


\section{References}

[1] Chen SF, Nieh S, Jao SW, Liu CL, Wu CH, Chang YC, et al. (2012) Quercetin suppresses drugresistant spheres via the p38 MAPK-Hsp27 apoptotic pathway in oral cancer cells. PLoS One 7: e49275. [2] Schultz CR, Golembieski WA, King DA, Brown SL, Brodie C, Rempel SA (2012) Inhibition of HSP27 alone or in combination with pAKT inhibition as therapeutic approaches to target SPARC-induced glioma cell survival. Mol Cancer 11: 20 (1-24)

[3] Russo M, Palumbo R, Tedesco I, Mazzarella G, Russo P, Iacomino G, et al. (1999) Quercetin and antiCD95(Fas/Apo1) enhance apoptosis in HPB-ALL cell line. FEBS Lett 462: 322-8.

[4] Min K, Ebeler SE (2008) Flavonoid effects on DNA oxidation at low concentrations relevant to physiological levels. Food Chem Toxicol 46: 96-104.

[5] Ghobrial IM, Witzig TE, Adjei A (2005) Targeting apoptosis pathways in cancer therapy. CA Cancer J Clin 5:178-94.

[6] Jakubowicz-Gil J, Langner E, Rzeski W (2011) Kinetic studies of the effects of Temodal and quercetin on astrocytoma cells. Pharmacol Rep 63:403-16.

[7]. Jakubowicz-Gil J, Langner E, Wertel I, Piersiak T, Rzeski W (2010) Temozolomide, quercetin and cell death in the MOGGCCM astrocytoma cell line. Chem Biol Inter 188:190-203.

[8] Jakubowicz-Gil J, Langner E, Badwiul D, Wertel I (2013) Silencing of Hsp27 and Hsp72 in glioma cells as a tool for programmed cell death induction upon temozolomide and quercetin treatment, Toxicol Appl Pharmacol 273: 580-589.

[9] Sang Dp, Li Rj, Lan Q (2014) Quercetin sensitizes human glioblastoma cells to temozolomide in vitro via inhibition of Hsp27, Acta Pharmacologica Sinica 35: 832-838

[10] Protsenko IO, Bulavin LA, Hovorun DM (2010) Investigation of Structural Properties of Quercetin by Quantum Chemistry Methods. WDS'10 Proceedings of Contributed Papers, Part III, 51-54,

[11] Wang X, Li S, Jiang X, Wang C (2015) Site-preference of Quercetin Hydrogen Bonding to Adenine. Chem J chinese 36: 932-938

[12] Filip X, Grosu IG, Miclăuş M, Filip C (2013) NMR crystallography methods to probe complex hydrogen bonding networks: application to structure elucidation of anhydrous quercetin. CrystEngComm 15: 4131-4142

[13] Pawlikowska-Pawlęga B, Dziubińska H, Król E, Trębacz K, Jarosz-Wilkołazka A, Paduch R, Gawron A, Gruszecki WI (2014) Characteristics of quercetin interactions with liposomal and vacuolar membranes. Biochim Biophys Acta 1838(1 Pt B):254-65

[14] Islam MR, Zaman A, Jahan I, Chakravorty R (2013) In silico QSAR analysis of quercetin reveals its potential as therapeutic drug for Alzheimer's disease. J Young Pharm 5:173-179.

[15] Bhat Q, Ahmad S (2015) Quantum chemical calculations and analysis of FTIR, FT-Raman and UV-

Vis spectra of temozolomide molecule. J Mol Struct 1099:453-462

[16] Kasende OE, Matondo A, Muzomwe M, Muya JT, Scheiner S (2014) Interaction between temozolomide and water: preferred binding sites. Comput Theor Chem 1034:26-29

[17] Kasende OE, Muya JT, Scheiner S (2015) Regioselectivity of the interaction of temozolomide with borane and boron trifluoride, Structural Chemistry 26:1359-1365

[18] Kasende OE, Matondo A, Muya JT, Scheiner S (2016) Interaction Between Temozolomide and $\mathrm{HCl}$ : Preferred Binding Sites. Comput Theor Chem 1075:82-86 
[19] Galek P, Pidcock E, Wood P (2011) CCDC, CSD Solid Form Suite, <http://

www.ccdc.cam.ac.uk/products/csd_solid_form_suite>

[20] Lowe PR, Sansom CE, Schwalbe CH, Stevens MF, Clark AS (1992) Antitumor imidazotetrazines. 25. Crystal structure of 8-carbamoyl-3-methylimidazo [5,1- d]-1,2,3,5-tetrazin-4(3H)-one (temozolomide) and structural comparisons with the related drugs mitozolomide and DTIC, J Med Chem 35:3377-3382

[21] Babu NJ, Sanphui P, Nangia A (2012) Crystal Engineering of stable temozolomide cocrystals. Chem Asian J 7:2274-2285

[22] Babu NJ, Sanphui P, Nath NK, Khandavilli UBR, Nangia A (2013) Temozolomide hydrochloride dehydrate. Cryst Eng Comm 15:666-671

[23] Kasende OE., Muya JT, Nziko VdePN, Scheiner S. Hydrogen Bonded and Stacked Geometries of the Temozolomide Dimer. J Mol Model 22:77 (1-9)

[24] Kasende OE., Muya JT, Nziko VdePN, Scheiner S. H-bonding and Stacking Interactions between Chloroquine and Temozolomide Int. J. Quantum Chem. (submitted)

[25] Hobza P, Müller-Dethlefs K (2010) Non-Covalent Interactions: Theory and Experiment. Royal Society of Chemistry Cambridge UK

[26] Karshikoff A (2006) Non-Covalent Interactions in Proteins. World Scientific, London

[27] Scheiner S (2015) Noncovalent Forces. Springer Switzland

[28] Maharramov AM, Mahmudov KT, Kopylovich MN, Pombeiro AJL (2016) Non-covalent Interactions in the Synthesis and Design of New Compounds. Wiley ISBN: 978-1-119-10989-1

[29] Lodish H (2000) Molecular Cell Biology. 4th edition WH Freeman New York USA

[30] Schuster P, Zundel G, Sandorfy C (Eds.) (1976) The hydrogen bond, Recent Developments in Theory and Experiments. North-Holland Publishing Co Amsterdam The Netherlands

[31] Schuster P (1984) Hydrogen Bonds. Springer-Verlag Berlin Germany p. 120 \

[32] Jeffrey GA, Saenger W (1991) Hydrogen Bonding in Biological Structures. Springer- Verlag Berlin Germany

[33] Scheiner S (1997) Hydrogen Bonding. A Theoretical Perspective. Oxford University Press New York USA

[34] Gilli G, Gilli P (2009) The Nature of the Hydrogen Bond. Oxford University Press Oxford UK

[35] Wieczorek R, Dannenberg JJ (2003) H-bonding cooperativity and energetics of helix formation of five 17-amino acid peptides. J Am Chem Soc 125:8124-8129

[36] Alabugin IV, Manoharan M, Peabody S, Weinhold F (2003) The electronic basis of improper hydrogen bonding: a subtle balance of hyperconjugation and rehybridization. J Am Chem Soc 125:5973-5987

[37] Hernández-Soto H, Weinhold F, Francisco JS (2007) Radical hydrogen bonding: origin of stability of radical-molecule complexes. J Chem Phys 127:164102-164110

[38] DelBene JE, Alkorta I, Elguero J (2011) An ab initio study of cooperative effects in ternary complexes $\mathrm{X}$ : $\mathrm{CNH}: \mathrm{Z}$ with $\mathrm{X}, \mathrm{Z}=\mathrm{CNH}, \mathrm{FH}, \mathrm{ClH}, \mathrm{FCl}$, and $\mathrm{HLi}$ : structures, binding energies, and spin-spin coupling constants across intermolecular bonds. Phys Chem Chem Phys 13:13951-13961

[39] Thakur TS, Kirchner MT, Blaser D, Boese R, Desiraju GR (2011) Nature and strength of C-H...O interactions involving formyl hydrogen atoms: computational and experimental studies of small aldehydes. Phys Chem Chem Phys 13:14076-14091 
[40] Mirzaei S, Khalilian MH, Taherpour AA (2015) Mechanistic study of the hydrolytic degradation and protonation of temozolomide RSC Adv 5: 41112-41119

[41] Becke AD (1993) Density-functional thermochemistry. III. The role of exact exchange. J Chem Phys 98:5648-5662

[42] Grimme S (2011) Density functional theory with London dispersion corrections. WIREs Computational Molecular Science John Wiley \& Sons Ltd pp. 211-228

[43] Zhao Y, Truhlar DG (2008) The M06 suite of density functionals for main group thermochemistry, thermochemical kinetics, noncovalent interactions, excited states,

and transition elements: two new functionals and systematic testing of four M06-class functionals and 12 other functionals. Theor Chem Account 120:215-241

[44] Walker M, Harvey AJA, Sen A, Dessent CEH (2013) Performance of M06, M06-2X, and M06-HF Density Functionals for Conformationally Flexible Anionic Clusters: M06 Functionals Perform Better than B3LYP for a Model System with Dispersion and Ionic Hydrogen-Bonding Interactions. J Phys Chem A 117:12590-12600

[45] Cohen AJ, Mori-Sánchez P, Yang W (2012) Challenges for Density Functional Theory. Chemical Reviews 112:289-320

[46] Hohenstein EG, Chill ST, Sherrill CD (2008) Assessment of the Performance of the M05-2X and M06-2X Exchange-Correlation Functionals for Noncovalent Interactions in Biomolecules. J Chem Theor Comput 4:1996-2000

[47] Riley KE, Pitoňák M, Jurečka P, Hobza P (2010) Stabilization and Structure Calculations for Noncovalent Interactions in Extended Molecular Systems Based on Wave Function and Density Functional Theories. Chem Rev 110: 5023-63

[48] Ferrighi L, Pan Y, Grönbeck H, Hammer B (2012) Stabilization and Structure Calculations for Noncovalent Interactions in Extended Molecular Systems Based on Wave Function and Density Functional Theories. J Phys Chem 116:7374-7379

[49] Chai JD, Head M (2008) Long-range corrected hybrid density functional with damped atom-atom dispersion corrections. Phys Chem Chem Phys 10: 6615-6620

[50] DiLabio GA, Johnson ER, Otero-de-la-Roza A (2013) Performance of conventional and dispersioncorrected density-functional theory methods for hydrogen bonding interaction energies, Phys Chem Chem Phys 15:12821-12828

[51] Gutowski M, van Duijneveldt van de Rijdt JGCM, van Lenthe JH, van Duijneveldt FB (1993) Accuracy of the boys and bernardi function counterpoise method. J Chem Phys 98:4728-4738

[52] Boys SF, Bernardi F (1970) The calculation of small molecular interactions by the difference of separate total energies. Some procedures with reduced errors. Mol Phys 19:553-566

[53] Grimme S, Antony J, Ehrlich S, Krieg H (2010) A consistent and accurate ab initio parametrization of density functional dispersion correction (DFT-D) for the 94 elements H-Pu J Chem Phys 132:154104 $-19$

[54] Grimme S, Ehrlich S, Goerigk L (2011) Effect of the damping function in dispersion corrected density functional theory. J Comput Chem 32:1456-65

[55] Becke AD, Johnson ER (2005) Exchange-hole dipole moment and the ospersion interaction. J Chem Phys 122:154104-4

[56] Johnson ER, Becke AD (2005) A density-functional model of the dispersion interaction J Chem Phys 
123:024101-1

[57] Axilrod BM, Teller E (1943) "Interaction of the van der Waals Type Between Three Atoms J Chem Phys 11:299-300

[58] Mutto J (1943) Force between non-polar molecules Proc. Phys. Math. Soc. Japan, 17:629-31

[59] See http://www.thch.uni-bonn.de/.

[60] Dennington R, Keith T, Millan J (2009) GaussView, version 5, Semichem. Inc., Shawnee Mission, KS

[61] Frisch MJ, Trucks GW, Schlegel HB, Scuseria GE, Robb MA, Cheeseman JR, Scalmani G, Barone V, Mennucci B, Petersson GA et al. (2009) Gaussian 09, revision A.02, Gaussian Inc., Wallingford, CT

[62] Glendening ED, Badenhoop JK, Reed AE, Carpenter JE, Bohmann JA, Morales CM, Landis CR, and Weinhold F (2013) NBO 6.0. Theoretical Chemistry Institute, University of Wisconsin, Madison.

[63] Bader RFW (1990) Atoms in Molecules, A Quantum Theory. Clarendon Press: Oxford, UK Vol. 22, p 438

[64] Carroll MT, Chang C, Bader RFW (1988) Mol Phys 63:387-405

[65] Keith TA (2013) AIMALL, TK Gristmill Software: Overland Park, KS

[66] Espinosa E, Molins E, Lecomte C (1998) Hydrogen bond strengths revealed by topological analyses of experimentally observed electron densities. Chem Phys Lett 285:170-173

[67] Yang L, Brazier JB, Hubbard TA, Rogers DM, Cockroft SL (2016) Can Dispersion Forces Govern Aromatic Stacking in an Organic Solvent? Angew. Chem. Int. Ed. 55:912-916.

[68] Dev S, Giri K, Majumder M, Sathyamurthy N (2015) Relative stabilities and the spectral signatures of stacked and hydrogen-bonded dimers of serotonin. Mol Phys 113:2952-2959.

[69] Reid SA, Nyambo S, Muzangwa L, Uhler B (2013) p-Stacking, C-H/p, and Halogen Bonding Interactions in Bromobenzene and Mixed Bromobenzene-Benzene Clusters. J Phys Chem A 117:13556-13563.

[70] Wang W, Zhang Y, Wang Y (2013) Unexpected strong stacking interactions between the homogeneous dimers of C6FxI (6-x) (x=0,1,1,1,1 and 5). Comput Theor Chem 1023:88-94.

[71] Kumar S, Das A (2013) Observation of exclusively p-stacked heterodimer of indole and hexafluorobenzene in the gas phase. J Chem Phys 139:104311.

[72] Cozzi F, Cinquini M, Annuziata R, Siegel JS (1993) Dominance of polar/.pi. over charge-transfer effects in stacked phenyl interactions. J Am Chem Soc 115:5330-5331.

[73] Leist R, Frey JA, Leutwyler S (2006) Fluorobenzen-nucleobase inteactions: Hydrogen bonding or pstacking? J Phys Chem A 110:4180-4187. 
Table 1. Binding energies BE, NBO second-order perturbation energy E $(2)(\mathrm{kJ} / \mathrm{mol})$ in QUA-TMZ dimers with $6-31+\mathrm{G}^{* *}$ basis set

\begin{tabular}{|c|c|c|c|c|c|c|}
\hline \multirow[t]{2}{*}{ Dimer } & \multicolumn{4}{|c|}{$\mathrm{BE}(\mathrm{kJ} / \mathrm{mol})$} & \multirow[b]{2}{*}{ QUA...TMZ } & \multirow{2}{*}{$\begin{array}{l}\mathrm{NBOE(2)} \\
(\mathrm{kJ} / \mathrm{mol})\end{array}$} \\
\hline & M06-2X & $\omega \mathrm{B} 97 \mathrm{XD}$ & B3LYP-D3 & MP2 & & \\
\hline AS1 & -75.61 & -73.59 & -65.75 & -51.48 & $\begin{array}{l}\mathrm{O}_{7}-\mathrm{H}_{10}\left(\sigma^{*}\right) \leftarrow \mathrm{O}_{9}(\mathrm{LPs}) \\
\mathrm{O}_{7}-\mathrm{H}_{10}\left(\sigma^{*}\right) \leftarrow \mathrm{C}_{21}-\mathrm{O}_{9}(\pi) \\
\mathrm{O}_{5}(\mathrm{LPs}) \rightarrow \mathrm{C}_{18}-\mathrm{H}_{11}\left(\sigma^{*}\right) \\
\mathrm{O}_{6}(\mathrm{LPs}) \rightarrow \mathrm{C}_{21}-\mathrm{O}_{9}\left(\pi^{*}\right)\end{array}$ & $\begin{array}{l}40.17 \\
10.75 \\
5.98 \\
3.35\end{array}$ \\
\hline AS2 & -68.51 & -65.14 & -61.53 & -41.69 & $\begin{array}{l}\mathrm{O}_{4}-\mathrm{H}_{7}\left(\sigma^{*}\right) \leftarrow \mathrm{O}_{9}(\mathrm{LPs}) \\
\mathrm{C}_{7}-\mathrm{C}_{8}(\pi) \rightarrow \mathrm{C}_{16}-\mathrm{N}_{4}\left(\pi^{*}\right) \\
\mathrm{O}_{4}-\mathrm{H}_{7}\left(\sigma^{*}\right) \leftarrow \mathrm{C}_{21}-\mathrm{O}_{9}(\pi) \\
\mathrm{C}_{4}-\mathrm{O}_{2}(\pi) \rightarrow \mathrm{C}_{18}-\mathrm{H}_{13}\left(\sigma^{*}\right) \\
\mathrm{C}_{7}-\mathrm{C}_{8}(\pi) \rightarrow \mathrm{N}_{2}-\mathrm{N}_{3}\left(\pi^{*}\right)\end{array}$ & $\begin{array}{l}57.82 \\
8.66 \\
5.31 \\
2.76 \\
2.34\end{array}$ \\
\hline AS3 & -62.54 & -59.12 & -53.18 & -35.69 & $\begin{array}{l}\mathrm{O}_{7}-\mathrm{H}_{10}\left(\sigma^{*}\right) \leftarrow \mathrm{O}_{8}(\mathrm{LPs}) \\
\mathrm{O}_{6}(\mathrm{LPs}) \rightarrow \mathrm{C}_{18}-\mathrm{H}_{12}\left(\sigma^{*}\right) \\
\mathrm{O}_{7}-\mathrm{H}_{10}\left(\sigma^{*}\right) \leftarrow \mathrm{C}_{17}-\mathrm{O}_{8}(\pi) \\
\mathrm{C}_{11}-\mathrm{C}_{12}(\pi) \rightarrow \mathrm{C}_{17}-\mathrm{O}_{8}\left(\pi^{*}\right) \\
\mathrm{C}_{1}-\mathrm{C}_{5}(\pi) \rightarrow \mathrm{C}_{21}-\mathrm{O}_{9}\left(\pi^{*}\right) \\
\mathrm{C}_{4}-\mathrm{O}_{2}\left(\pi^{*} \leftarrow \mathrm{C}_{21}-\mathrm{O}_{9}(\pi)\right. \\
\mathrm{C}_{10}-\mathrm{C}_{15}\left(\sigma^{*}\right) \leftarrow \mathrm{C}_{17}-\mathrm{O}_{8}(\pi) \\
\mathrm{C}_{4}-\mathrm{O}_{2}(\pi) \rightarrow \mathrm{N}_{6}-\mathrm{H}_{14}\left(\sigma^{*}\right)\end{array}$ & $\begin{array}{l}12.84 \\
10.92 \\
7.32 \\
4.90 \\
4.10 \\
2.30 \\
2.30 \\
2.13\end{array}$ \\
\hline AS4 & -61.15 & -56.50 & -50.32 & -34.59 & $\begin{array}{l}\mathrm{O}_{5}-\mathrm{H}_{8}\left(\sigma^{*}\right) \leftarrow \mathrm{O}_{9}(\mathrm{LPs}) \\
\mathrm{O}_{7}-\mathrm{H}_{10}\left(\sigma^{*}\right) \leftarrow \mathrm{O}_{8}(\mathrm{LPs}) \\
\mathrm{O}_{5}-\mathrm{H}_{8}\left(\sigma^{*}\right) \leftarrow \mathrm{C}_{21}-\mathrm{O}_{9}(\pi) \\
\mathrm{O}_{7}-\mathrm{H}_{10}\left(\sigma^{*}\right) \leftarrow \mathrm{C}_{17}-\mathrm{O}_{8}(\pi) \\
\mathrm{C}_{10}-\mathrm{C}_{15}(\pi) \rightarrow \mathrm{C}_{17}-\mathrm{O}_{8}\left(\pi^{*}\right) \\
\mathrm{O}_{6}(\mathrm{LPs}) \rightarrow \mathrm{C}_{18}-\mathrm{H}_{11}\left(\sigma^{*}\right) \\
\mathrm{O}_{5}(\mathrm{LPs}) \rightarrow \mathrm{N}_{2}-\mathrm{N}_{3}\left(\pi^{*}\right)\end{array}$ & $\begin{array}{l}31.17 \\
10.04 \\
9.04 \\
6.49 \\
4.81 \\
4.56 \\
2.43\end{array}$ \\
\hline AS5 & -57.98 & -57.53 & -48.49 & -35.18 & $\begin{array}{l}\mathrm{O}_{7}-\mathrm{H}_{10}\left(\sigma^{*}\right) \leftarrow \mathrm{N}_{6}(\mathrm{LP}) \\
\mathrm{C}_{11}-\mathrm{C}_{12}(\pi) \rightarrow \mathrm{C}_{20}-\mathrm{N}_{5}\left(\pi^{*}\right) \\
\mathrm{C}_{13}-\mathrm{C}_{14}(\pi) \rightarrow \mathrm{C}_{17}-\mathrm{O}_{8}\left(\pi^{*}\right) \\
\mathrm{O}_{5}(\mathrm{LPs}) \rightarrow \mathrm{C}_{18}-\mathrm{H}_{11}\left(\sigma^{*}\right)\end{array}$ & $\begin{array}{l}35.77 \\
4.56 \\
2.64 \\
1.92 \\
\end{array}$ \\
\hline AHB6 & -52.95 & -53.31 & -50.92 & -23.17 & $\begin{array}{l}\mathrm{O}_{4}-\mathrm{H}_{7}\left(\sigma^{*}\right) \leftarrow \mathrm{O}_{9}(\mathrm{LPs}) \\
\mathrm{O}_{4}(\mathrm{LPs}) \rightarrow \mathrm{N}_{6}-\mathrm{H}_{14}\left(\sigma^{*}\right) \\
\mathrm{O}_{4}-\mathrm{H}_{7}\left(\sigma^{*}\right) \leftarrow \mathrm{C}_{21}-\mathrm{O}_{9}(\pi) \\
\mathrm{O}_{4}-\mathrm{H}_{7}\left(\sigma^{*}\right) \leftarrow \mathrm{C}_{19}-\mathrm{C}_{21}(\pi)\end{array}$ & $\begin{array}{l}126.40 \\
15.31 \\
3.01 \\
1.92\end{array}$ \\
\hline AHB7 & -51.74 & -53.60 & -52.07 & -29.91 & $\begin{array}{l}\mathrm{O}_{7}-\mathrm{H}_{10}\left(\sigma^{*}\right) \leftarrow \mathrm{O}_{9}(\mathrm{LPs}) \\
\mathrm{C}_{15}-\mathrm{H}_{5}\left(\sigma^{*}\right) \leftarrow \mathrm{N}_{3}(\mathrm{LP}) \\
\mathrm{O}_{7}-\mathrm{H}_{10}\left(\sigma^{*}\right) \leftarrow \mathrm{C}_{21}-\mathrm{O}_{9}(\pi)\end{array}$ & $\begin{array}{l}115.14 \\
12.18 \\
2.38 \\
\end{array}$ \\
\hline AS8 & -49.19 & -45.65 & -32.88 & -19.95 & $\begin{array}{l}\mathrm{O}_{5}-\mathrm{H}_{8}\left(\sigma^{*}\right) \leftarrow \mathrm{O}_{9}(\mathrm{LPs}) \\
\mathrm{O}_{3}(\mathrm{LPs}) \rightarrow \mathrm{C}_{18}-\mathrm{H}_{11}\left(\sigma^{*}\right) \\
\mathrm{C}_{13}-\mathrm{C}_{14}(\pi) \rightarrow \mathrm{C}_{21}-\mathrm{O}_{9}\left(\pi^{*}\right) \\
\mathrm{C}_{4}-\mathrm{O}_{2}\left(\pi^{*}\right) \leftarrow \mathrm{N}_{2}-\mathrm{N}_{3}(\pi) \\
\mathrm{C}_{7}-\mathrm{C}_{8}\left(\pi^{*}\right) \leftarrow \mathrm{N}_{1}(\mathrm{LP})\end{array}$ & $\begin{array}{l}72.28 \\
11.51 \\
2.51 \\
2.05 \\
1.97 \\
\end{array}$ \\
\hline AHB9 & -48.92 & -48.47 & -49.52 & -17.59 & $\begin{array}{l}\mathrm{O}_{6}-\mathrm{H}_{9}\left(\sigma^{*} \leftarrow \mathrm{O}_{9}(\mathrm{LPs})\right. \\
\mathrm{O}_{7}-\mathrm{H}_{10}\left(\sigma^{*}\right) \leftarrow \mathrm{O}_{9}(\mathrm{LPs}) \\
\mathrm{O}_{6}(\mathrm{LPs}) \rightarrow \mathrm{N}_{6}-\mathrm{H}_{14}\left(\sigma^{*}\right)\end{array}$ & $\begin{array}{l}49.87 \\
49.71 \\
30.08 \\
\end{array}$ \\
\hline AHB10 & -47.00 & -48.47 & -46.22 & -20.11 & $\begin{array}{l}\mathrm{O}_{7}-\mathrm{H}_{10}\left(\sigma^{*}\right) \leftarrow \mathrm{O}_{9}(\mathrm{LPs}) \\
\mathrm{O}_{6}(\mathrm{LPs}) \rightarrow \mathrm{N}_{6}-\mathrm{H}_{14}\left(\sigma^{*}\right) \\
\mathrm{O}_{7}-\mathrm{H}_{10}\left(\sigma^{*} \leftarrow \mathrm{C}_{21}-\mathrm{O}_{9}(\pi)\right.\end{array}$ & $\begin{array}{l}83.68 \\
42.59 \\
5.06\end{array}$ \\
\hline
\end{tabular}




\begin{tabular}{|c|c|c|c|c|c|c|}
\hline AHB11 & -37.81 & -38.20 & -37.42 & -14.90 & $\begin{array}{l}\mathrm{O}_{5}-\mathrm{H}_{8}\left(\sigma^{*}\right) \leftarrow \mathrm{N}_{5}(\mathrm{LP}) \\
\mathrm{O}_{5}(\mathrm{LPs}) \rightarrow \mathrm{N}_{6}-\mathrm{H}_{15}\left(\sigma^{*}\right) \\
\mathrm{O}_{2}(\mathrm{LPs}) \rightarrow \mathrm{C}_{20}-\mathrm{H}_{10}\left(\sigma^{*}\right) \\
\mathrm{O}_{5}-\mathrm{H}_{8}\left(\sigma^{*}\right) \leftarrow \mathrm{C}_{20}-\mathrm{N}_{5}(\pi) \\
\mathrm{O}_{5}-\mathrm{H}_{8}\left(\sigma^{*}\right) \leftarrow \mathrm{C}_{19}-\mathrm{N}_{5}(\pi)\end{array}$ & $\begin{array}{l}106.90 \\
26.65 \\
6.15 \\
3.10 \\
2.71 \\
\end{array}$ \\
\hline AHB12 & -37.51 & -41.16 & -38.87 & -11.62 & $\begin{array}{l}\mathrm{O}_{7}-\mathrm{H}_{10}\left(\sigma^{*}\right) \leftarrow \mathrm{N}_{5}(\mathrm{LP}) \\
\mathrm{O}_{7}(\mathrm{LPs}) \rightarrow \mathrm{N}_{6}-\mathrm{H}_{15}\left(\sigma^{*}\right) \\
\mathrm{O}_{7}-\mathrm{H}_{10}\left(\sigma^{*}\right) \leftarrow \mathrm{C}_{19}-\mathrm{N}_{5}(\pi) \\
\mathrm{O}_{7}-\mathrm{H}_{10}\left(\sigma^{*}\right) \leftarrow \mathrm{C}_{20}-\mathrm{N}_{5}(\pi)\end{array}$ & $\begin{array}{l}141.25 \\
24.81 \\
4.18 \\
3.98\end{array}$ \\
\hline
\end{tabular}

Table 2. Comparison between B3LYP and B3LYP-D3 binding energies ( $\mathrm{kJ} / \mathrm{mol})$ of QUA-TMZ dimers, computed with 6-31+G** basis set

\begin{tabular}{|l|l|l|l|}
\hline Dimer & B3LYP-D3 & \multicolumn{1}{|c|}{ B3LYP } & \multicolumn{1}{c|}{$\Delta$ BE } \\
\hline AS1 & -65.75 & 23.29 & -89.04 \\
\hline AS2 & -61.53 & 2.79 & -64.32 \\
\hline AS3 & -53.18 & 37.93 & -91.11 \\
\hline AS4 & -50.32 & 21.19 & -71.51 \\
\hline AS5 & -48.49 & 33.45 & -81.94 \\
\hline AHB6 & -50.92 & -34.84 & -16.08 \\
\hline AHB7 & -52.07 & -36.28 & -15.79 \\
\hline AS8 & -32.88 & 68.25 & -101.13 \\
\hline AHB9 & -49.52 & -32.35 & -17.17 \\
\hline AHB10 & -46.22 & -27.40 & -18.82 \\
\hline AHB11 & -37.42 & -14.63 & -22.79 \\
\hline AHB12 & -38.87 & -18.42 & -20.45 \\
\hline
\end{tabular}


Table 3. Binding energies BE, NBO second-order perturbation energy E(2) (kJ/mol) in QUB-TMZ dimers with $6-31+\mathrm{G}^{* *}$ basis set. Values in italics are energies relative to AS1.

\begin{tabular}{|c|c|c|c|c|c|c|}
\hline \multirow[t]{2}{*}{ Dimer } & \multicolumn{4}{|c|}{$\mathrm{BE}(\mathrm{kJ} / \mathrm{mol})$} & \multirow{2}{*}{ QUB...TMZ } & \multirow{2}{*}{$\begin{array}{l}\mathrm{NBO} E(2) \\
(\mathrm{kJ} / \mathrm{mol}) \\
\end{array}$} \\
\hline & M06-2X & $\omega \mathrm{B} 97 \mathrm{XD}$ & B3LYP-D3 & MP2 & & \\
\hline BS1 & $\begin{array}{l}-85.00 \\
42.37\end{array}$ & $\begin{array}{l}-83.74 \\
41.59\end{array}$ & $\begin{array}{l}-78.01 \\
41.24\end{array}$ & $\begin{array}{l}-56.69 \\
45.47\end{array}$ & $\begin{array}{l}\mathrm{O}_{4}-\mathrm{H}_{7}\left(\sigma^{*}\right) \leftarrow \mathrm{O}_{9}(\mathrm{LPs}) \\
\mathrm{O}_{4}-\mathrm{H}_{7}\left(\sigma^{*}\right) \leftarrow \mathbf{C}_{21}-\mathrm{O}_{9}(\pi) \\
\mathrm{C}_{13}-\mathrm{C}_{14}(\pi) \rightarrow \mathbf{C}_{18}-\mathrm{H}_{12}\left(\sigma^{*}\right) \\
\mathrm{C}_{6}-\mathrm{C}_{9}(\pi) \rightarrow \mathbf{N}_{3}-\mathrm{N}_{2}\left(\pi^{*}\right) \\
\mathbf{C}_{6}-\mathrm{H}_{1}\left(\sigma^{*}\right) \leftarrow \mathbf{C}_{21}-\mathrm{O}_{9}\left(\pi^{*}\right) \\
\mathbf{C}_{2}-\mathrm{C}_{3}\left(\pi^{*}\right) \leftarrow \mathbf{N}_{3}-\mathrm{N}_{2}(\pi)\end{array}$ & $\begin{array}{l}45.06 \\
4.98 \\
4.02 \\
2.89 \\
2.22 \\
2.13 \\
\end{array}$ \\
\hline BS2 & $\begin{array}{l}-77.97 \\
49.40\end{array}$ & $\begin{array}{l}-68.73 \\
56.59\end{array}$ & $\begin{array}{l}-62.62 \\
56.63\end{array}$ & $\begin{array}{l}-43.78 \\
58.39\end{array}$ & $\begin{array}{l}\mathrm{O}_{3}-\mathrm{H}_{6}\left(\sigma^{*}\right) \leftarrow \mathrm{O}_{9}(\mathrm{LPs}) \\
\mathrm{O}_{5}-\mathrm{H}_{8}\left(\sigma^{*}\right) \leftarrow \mathbf{C}_{17}-\mathrm{O}_{8}(\pi) \\
\mathrm{O}_{3}-\mathrm{H}_{6}\left(\sigma^{*}\right) \leftarrow \mathbf{C}_{21}-\mathrm{O}_{9}(\pi) \\
\mathrm{O}_{2}(\mathrm{LPs}) \rightarrow \mathbf{C}_{17}-\mathrm{O}_{8}\left(\pi^{*}\right) \\
\mathrm{O}_{5}-\mathrm{H}_{8}\left(\sigma^{*}\right) \leftarrow \mathrm{O}_{8}(\mathrm{LPs})\end{array}$ & $\begin{array}{l}20.79 \\
7.07 \\
6.78 \\
5.86 \\
2.13 \\
\end{array}$ \\
\hline BS3 & $\begin{array}{l}-77.06 \\
50.31\end{array}$ & $\begin{array}{l}-74.34 \\
50.98\end{array}$ & $\begin{array}{l}-66.40 \\
52.85\end{array}$ & $\begin{array}{l}-52.75 \\
49.42\end{array}$ & $\begin{array}{l}\mathrm{O}_{7}-\mathrm{H}_{10}\left(\sigma^{*}\right) \leftarrow \mathrm{O}_{9}(\mathrm{LPs}) \\
\mathrm{O}_{7}-\mathrm{H}_{10}\left(\sigma^{*}\right) \leftarrow \mathrm{C}_{21}-\mathrm{O}_{9}(\pi) \\
\mathrm{O}_{5}(\mathrm{LPs}) \rightarrow \mathrm{H}_{13}-\mathrm{C}_{18}\left(\sigma^{*}\right) \\
\mathrm{O}_{6}(\mathrm{LPs}) \rightarrow \mathbf{C}_{43}-\mathrm{O}_{46}\left(\pi^{*}\right) \\
\mathrm{C}_{1}-\mathrm{C}_{5}(\pi) \rightarrow \mathrm{C}_{17}-\mathrm{O}_{8}\left(\pi^{*}\right)\end{array}$ & $\begin{array}{l}35.61 \\
11.76 \\
5.48 \\
3.10 \\
1.92 \\
\end{array}$ \\
\hline BHB4 & $\begin{array}{l}-72.28 \\
55.09\end{array}$ & $\begin{array}{l}-71.09 \\
54.24\end{array}$ & $\begin{array}{l}-70.64 \\
48.61\end{array}$ & $\begin{array}{l}-41.46 \\
60.71\end{array}$ & $\begin{array}{l}\mathrm{O}_{3}-\mathrm{H}_{6}\left(\sigma^{*}\right) \leftarrow \mathrm{O}_{9}(\mathrm{LPs}) \\
\mathrm{O}_{2}(\mathrm{LPs}) \rightarrow \mathrm{N}_{6}-\mathrm{H}_{14}\left(\sigma^{*}\right) \\
\mathrm{O}_{3}(\mathrm{LPs}) \rightarrow \mathrm{N}_{6}-\mathrm{H}_{14}\left(\sigma^{*}\right) \\
\mathrm{O}_{3}-\mathrm{H}_{6}\left(\sigma^{*}\right) \leftarrow \mathrm{C}_{21}-\mathrm{O}_{9}(\pi)\end{array}$ & $\begin{array}{l}178.82 \\
38.37 \\
21.21 \\
5.48 \\
\end{array}$ \\
\hline BS5 & $\begin{array}{l}-67.78 \\
60.35\end{array}$ & $\begin{array}{l}-60.25 \\
65.07\end{array}$ & $\begin{array}{l}-53.66 \\
65.59\end{array}$ & $\begin{array}{l}-40.06 \\
62.10\end{array}$ & $\begin{array}{l}\mathrm{O}_{4}-\mathrm{H}_{9}\left(\sigma^{*}\right) \leftarrow \mathrm{O}_{9}(\mathrm{LPs}) \\
\mathrm{O}_{4}-\mathrm{H}_{9}\left(\sigma^{*}\right) \leftarrow \mathrm{C}_{21}-\mathrm{O}_{9}(\pi) \\
\mathrm{C}_{4}-\mathrm{O}_{2}(\pi) \rightarrow \mathrm{C}_{18}-\mathrm{H}_{12}\left(\sigma^{*}\right) \\
\mathrm{C}_{11}-\mathrm{C}_{12}(\pi) \rightarrow \mathrm{C}_{21}-\mathrm{O}_{9}\left(\pi^{*}\right) \\
\mathrm{O}_{2}(\mathrm{LPs}) \rightarrow \mathrm{C}_{18}-\mathrm{H}_{12}\left(\sigma^{*}\right) \\
\mathrm{C}_{4}-\mathrm{O}_{2}\left(\pi^{*}\right) \leftarrow \mathrm{N}_{1}(\mathrm{LP}) \\
\mathrm{C}_{2}-\mathrm{C}_{3}\left(\pi^{*}\right) \rightarrow \mathrm{N}_{3}-\mathrm{N}_{2}(\pi) \\
\mathrm{C}_{11}-\mathrm{C}_{12}\left(\pi^{*}\right) \leftarrow \mathrm{N}_{6}(\mathrm{LP})\end{array}$ & $\begin{array}{l}17.70 \\
8.87 \\
5.94 \\
5.86 \\
3.97 \\
3.81 \\
2.38 \\
2.09\end{array}$ \\
\hline BS6 & $\begin{array}{l}-58.70 \\
68.67\end{array}$ & $\begin{array}{l}-52.27 \\
73.06\end{array}$ & $\begin{array}{l}-42.86 \\
76.39\end{array}$ & $\begin{array}{l}-28.98 \\
73.18\end{array}$ & $\begin{array}{l}\mathrm{O}_{7}-\mathrm{H}_{10}\left(\sigma^{*}\right) \leftarrow \mathrm{O}_{8}(\mathrm{LPs}) \\
\mathrm{O}_{7}-\mathrm{H}_{10}\left(\sigma^{*}\right) \leftarrow \mathrm{C}_{17}-\mathrm{O}_{8}(\pi) \\
\mathrm{C}_{10}-\mathrm{C}_{15}(\pi) \rightarrow \mathrm{C}_{17}-\mathrm{O}_{8}\left(\pi^{*}\right) \\
\mathrm{O}_{5}-\mathrm{H}_{8}\left(\sigma^{*}\right) \leftarrow \mathrm{C}_{21}-\mathrm{O}_{9}(\pi) \\
\mathrm{C}_{11}-\mathrm{C}_{12}(\pi) \rightarrow \mathrm{C}_{20}-\mathrm{N}_{5}\left(\pi^{*}\right) \\
\mathrm{O}_{5}-\mathrm{H}_{8}\left(\sigma^{*}\right) \leftarrow \mathrm{O}_{9}(\mathrm{LPs}) \\
\mathrm{C}_{1}-\mathrm{C}_{5}(\pi) \rightarrow \mathrm{C}_{21}-\mathrm{O}_{9}\left(\pi^{*}\right) \\
\mathrm{C}_{4}-\mathrm{O}_{2}\left(\pi^{*}\right) \leftarrow \mathrm{N}_{5}(\mathrm{LP}) \\
\mathrm{C}_{1}-\mathrm{C}_{5}(\pi) \rightarrow \mathrm{C}_{16}-\mathrm{C}_{19}\left(\pi^{*}\right)\end{array}$ & $\begin{array}{l}17.87 \\
10.21 \\
7.07 \\
4.94 \\
4.52 \\
3.64 \\
2.72 \\
2.68 \\
2.18 \\
\end{array}$ \\
\hline BHB7 & $\begin{array}{l}-46.67 \\
80.70\end{array}$ & $\begin{array}{l}-44.45 \\
80.88\end{array}$ & $\begin{array}{l}-44.27 \\
74.98\end{array}$ & $\begin{array}{l}-17.83 \\
84.33\end{array}$ & $\begin{array}{l}\mathrm{O}_{5}-\mathrm{H}_{8}\left(\sigma^{*}\right) \leftarrow \mathrm{O}_{9}(\mathrm{LPs}) \\
\mathrm{O}_{2}(\mathrm{LPs}) \rightarrow \mathrm{N}_{6}-\mathrm{H}_{14}\left(\sigma^{*}\right)\end{array}$ & $\begin{array}{l}85.69 \\
54.39\end{array}$ \\
\hline BHB8 & $\begin{array}{l}-38.39 \\
88.98\end{array}$ & $\begin{array}{l}-35.67 \\
89.66\end{array}$ & $\begin{array}{l}-34.34 \\
84.91\end{array}$ & $\begin{array}{l}-9.40 \\
92.75\end{array}$ & $\begin{array}{l}\mathrm{O}_{4}-\mathrm{H}_{9}\left(\sigma^{*}\right) \leftarrow \mathrm{O}_{9}(\mathrm{LPs}) \\
\mathrm{O}_{4}(\mathrm{LPs}) \rightarrow \mathrm{N}_{6}-\mathrm{H}_{14}\left(\sigma^{*}\right)\end{array}$ & $\begin{array}{l}77.40 \\
22.13\end{array}$ \\
\hline
\end{tabular}


Table 4. Comparison between B3LYP and B3LYP-D3 binding energies (kJ/mol) of QUB-TMZ dimers, computed with $6-31+\mathrm{G}^{* *}$ basis set

\begin{tabular}{|l|l|l|l|}
\hline Dimer & B3LYP-D3 & B3LYP & $\Delta$ BE \\
\hline BS1 & -78.01 & 4.99 & -83.00 \\
\hline BS2 & -62.62 & 6.42 & -69.04 \\
\hline BS3 & -66.40 & 22.79 & -89.19 \\
\hline BHB4 & -70.64 & -53.19 & -20.45 \\
\hline BS5 & -53.66 & 42.29 & -95.95 \\
\hline BS6 & -42.86 & 45.16 & -88.02 \\
\hline BHB7 & -44.27 & -30.63 & -13.64 \\
\hline BHB8 & -34.34 & -23.01 & -11.33 \\
\hline
\end{tabular}



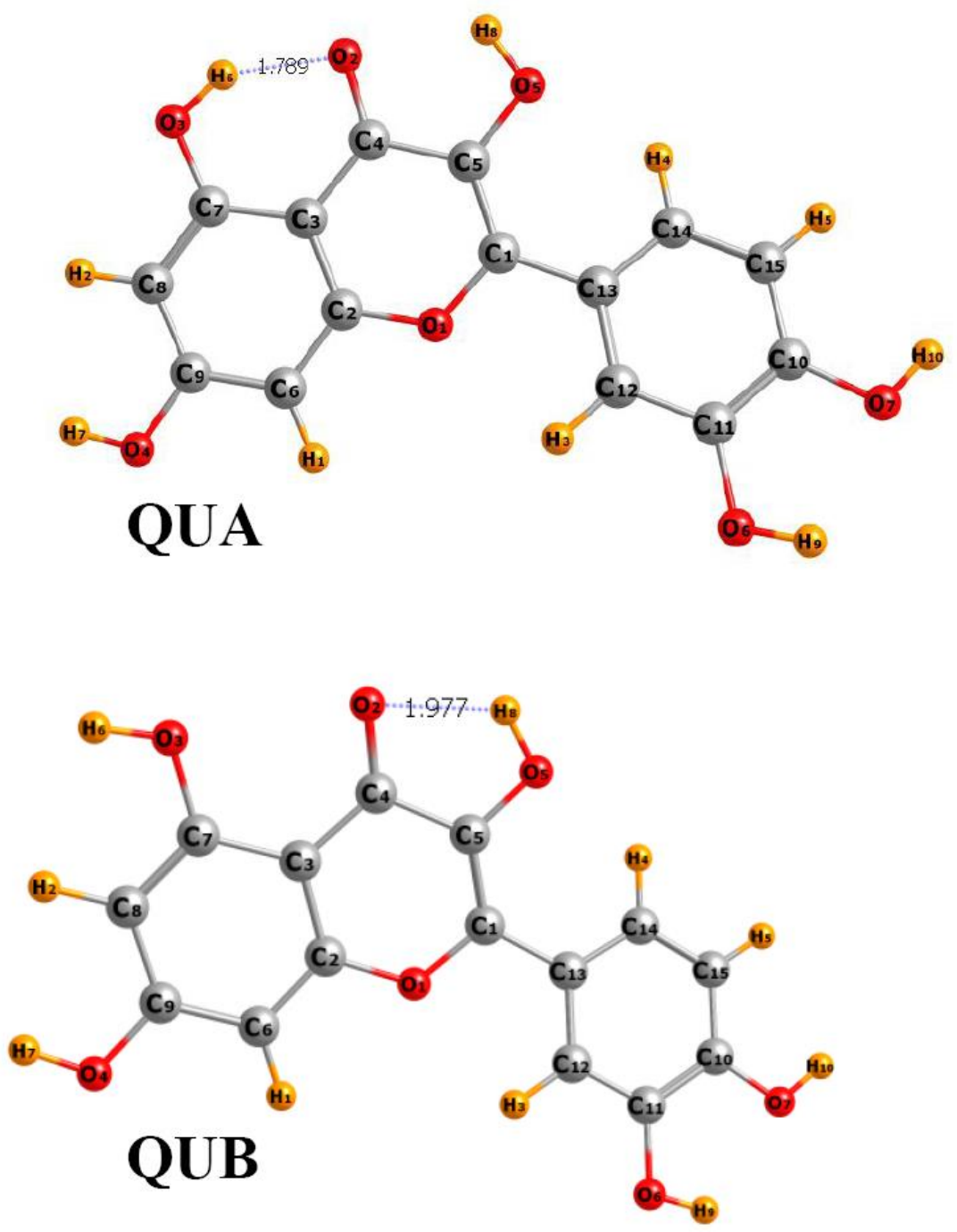

Fig 3. Structures of two conformers of QU 


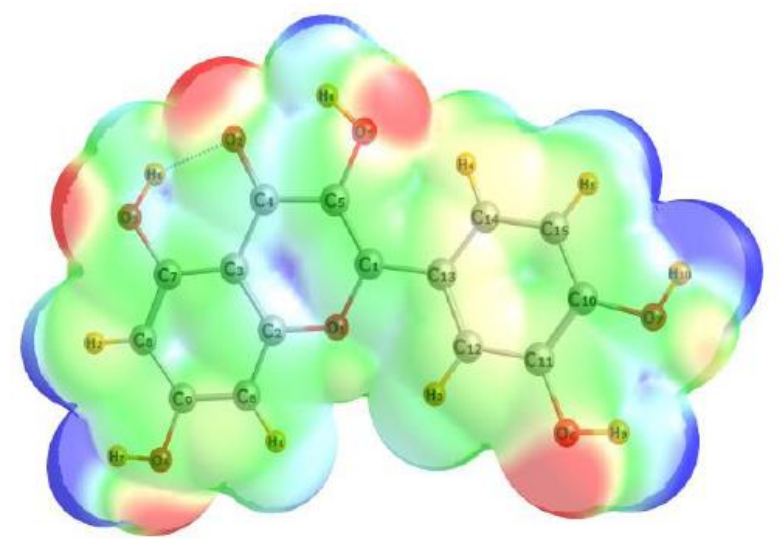

a) QUA

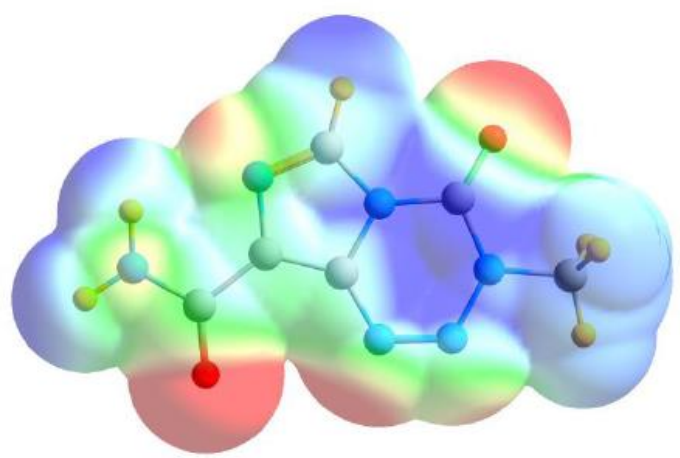

b) $\mathrm{TMZ}$

Fig 4. Molecular electrostatic potential surrounding a) QUA and b) TMZ on surface representing 1.5 times the van der Waals radius of each atom. Blue color indicates a potential of $+0.05 \mathrm{au}$, and red corresponds to -0.05 . 


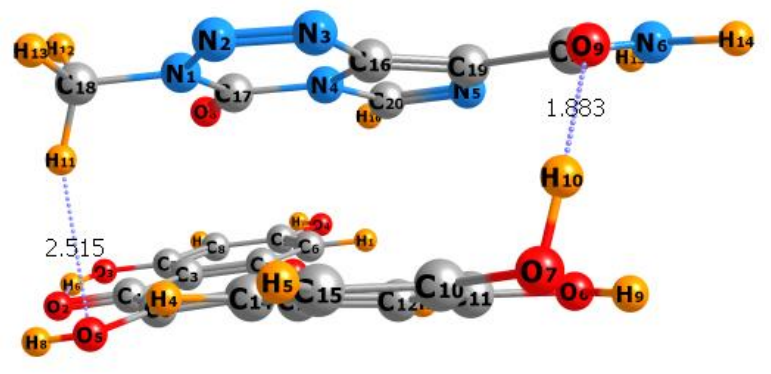

AS1
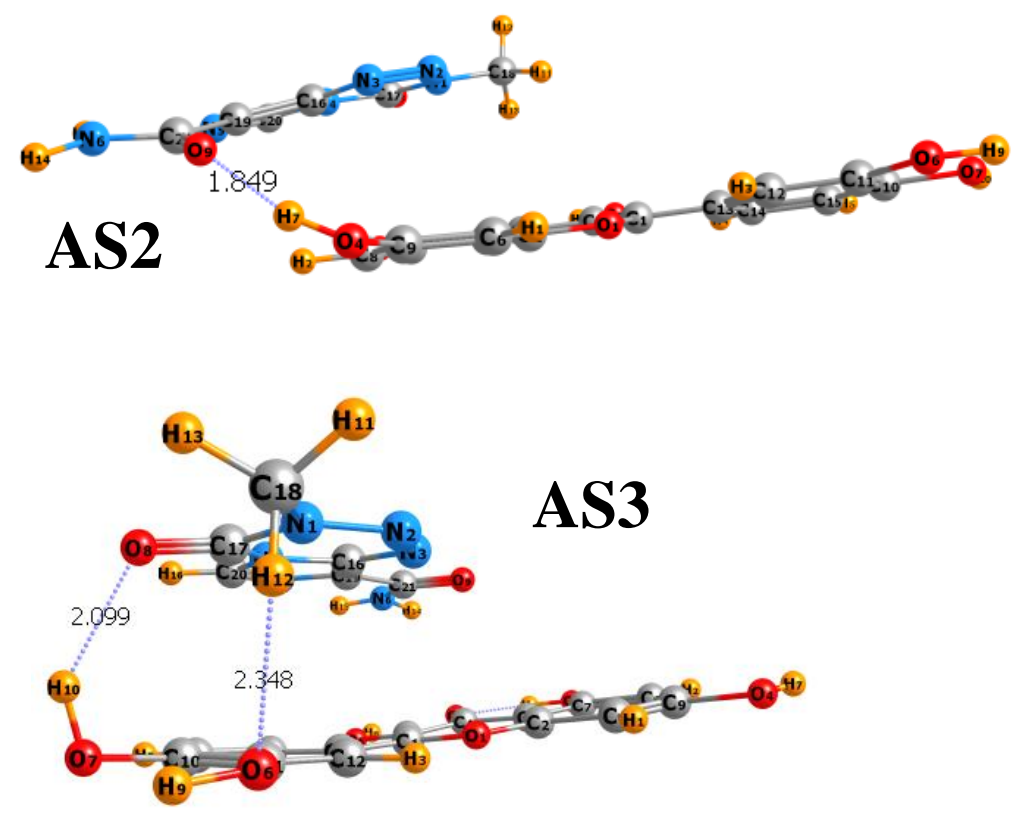

Fig 5. Three most stable stacked complexes of TMZ with QUA 

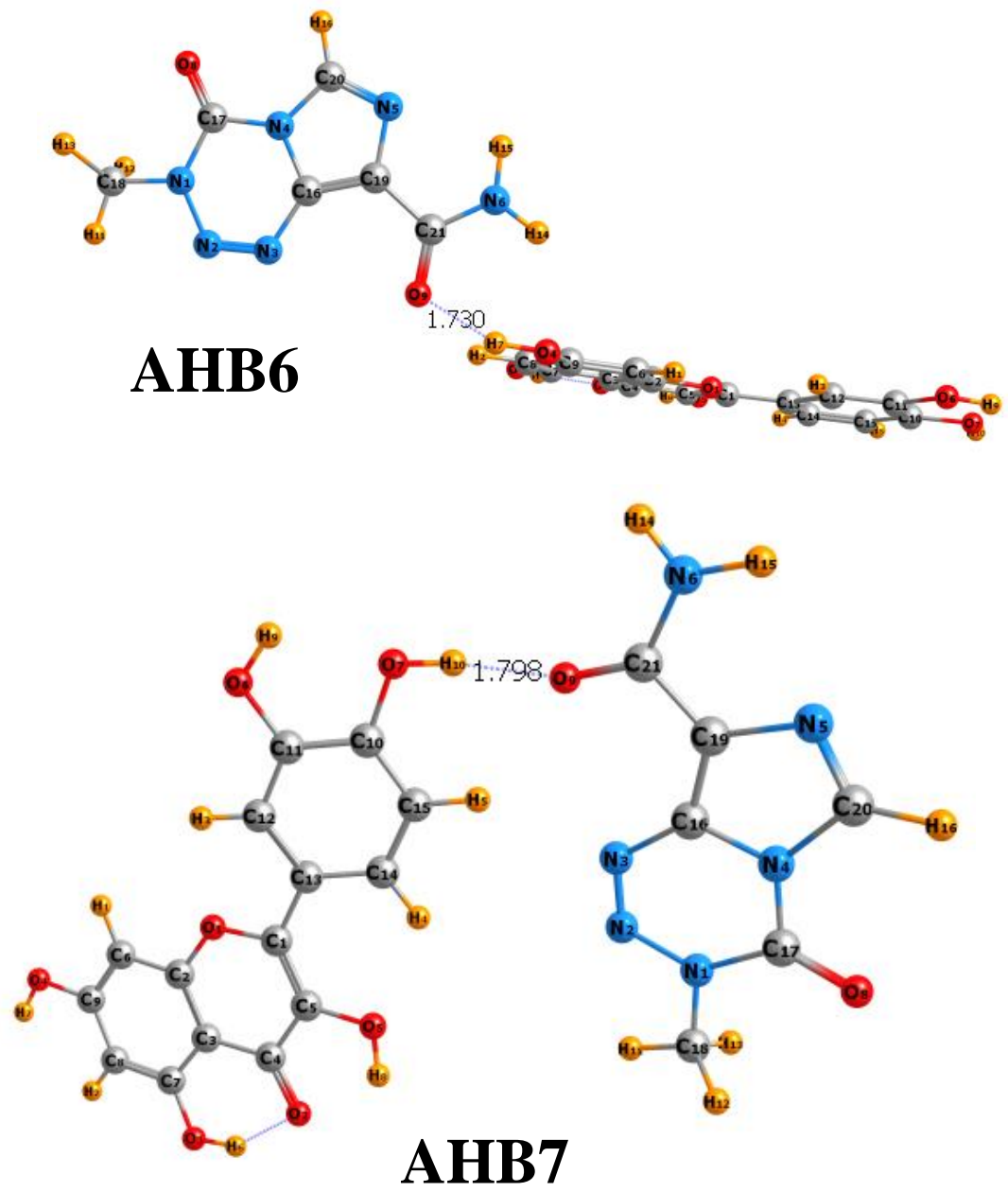

Fig 6. Two most stable H-bonded complexes of TMZ with QUA 

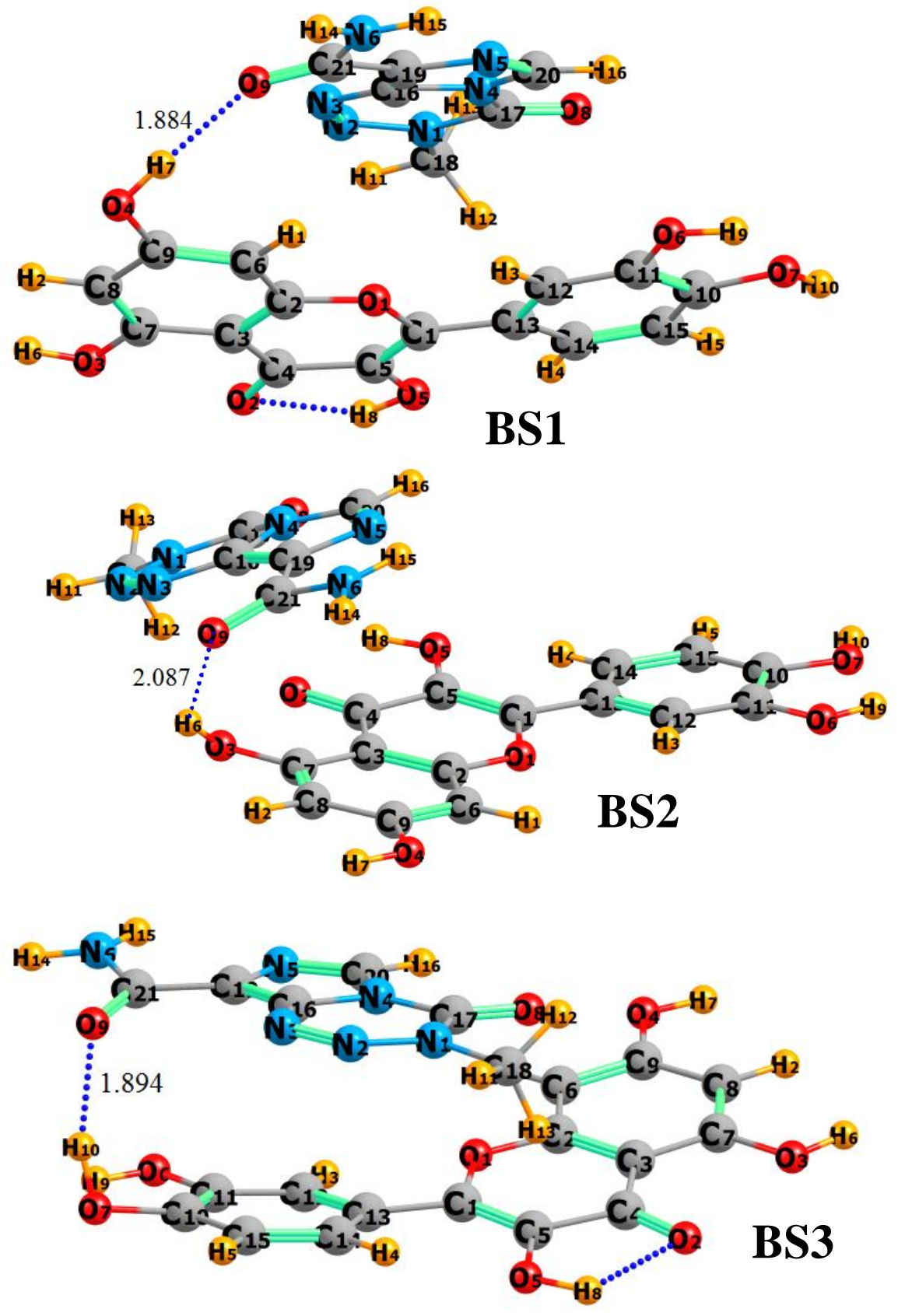

Fig 7. Three most stable stacked complexes of TMZ with QUB 


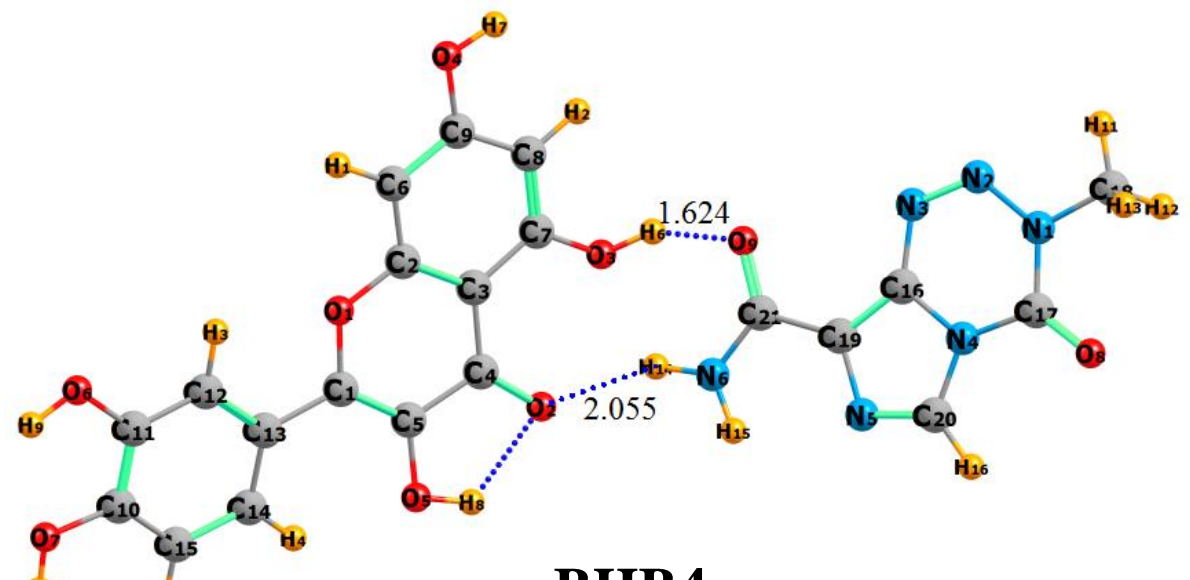

\section{BHB4}

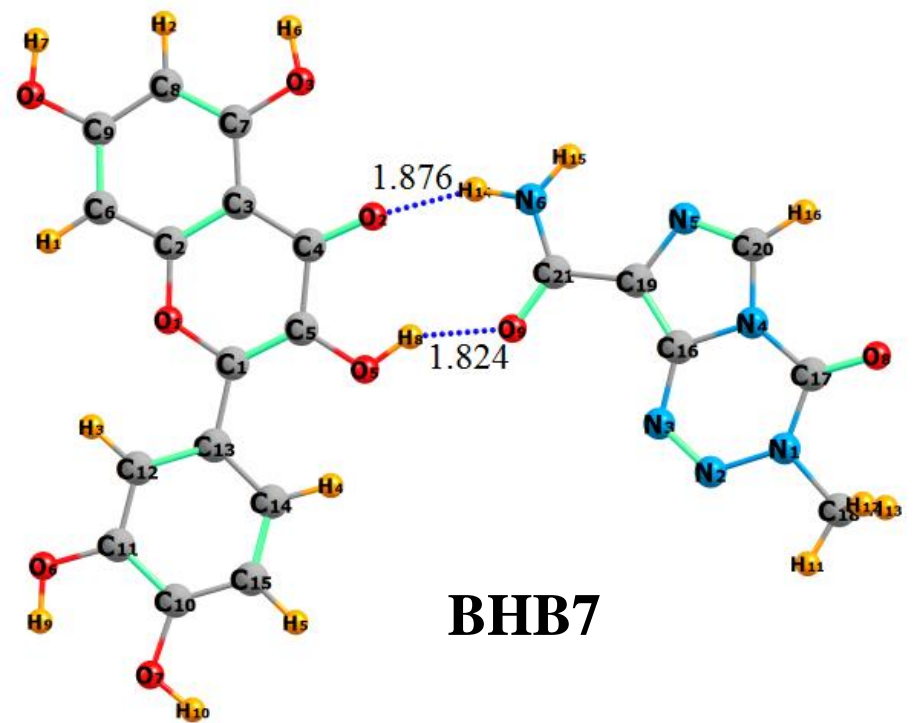

Fig 8. Two most stable H-bonded complexes of TMZ with QUB 
TOC graphic:

$\pi-\pi$ stacking preferable to strong $\mathrm{H}$-bonds
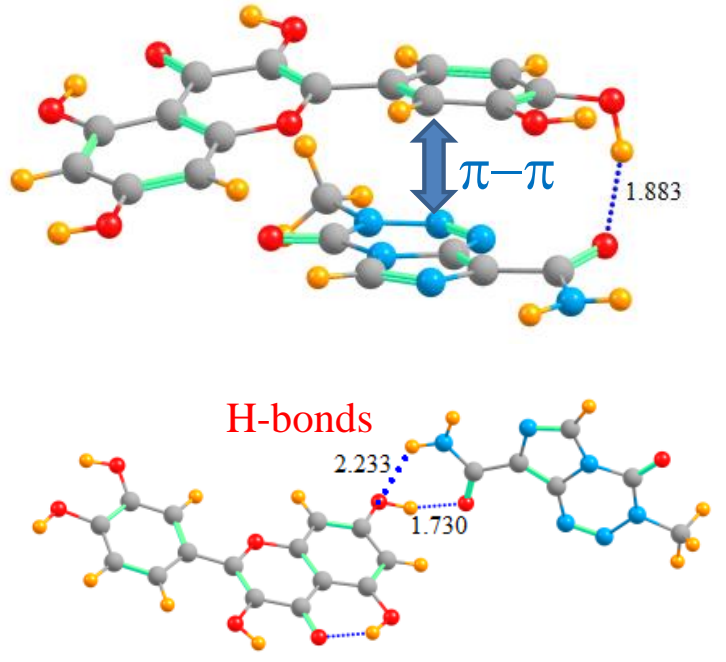